\title{
Inter- and Intra-Marriage Premiums Revisited: It's probably who you are, not who you marry! ${ }^{\uparrow}$
}

\author{
Lena Nekby*
}

\begin{abstract}
For immigrants, intermarriage with natives is assumed to have an assimilating role due to the enhancement of local human capital such a union creates in the form of improved knowledge about host country institutions, language and customs as well as access to native spouses' networks and contacts. However, marriage choice is endogenous, unobserved factors influence who we marry and our labor market outcomes. This study uses panel data on immigrants and their spouses in Sweden to estimate marriage premiums taking into account individual heterogeneity. This is done for three types of marriages; intermarriage to natives and intra-marriage with immigrants from home countries or other (non-Swedish) countries. A staggered fixed effects model is estimated separately for each marriage type to further disentangle a causal effect of intermarriage (intra-marriage) on annual income from any remaining positive selection effects into respective marriage type. Results from fixed effects estimation indicate that all types of marriage (with one exception) yield positive marriage premiums of similar magnitude. Significant pre-marriage income growth and a lack of postmarriage income growth for those that marry natives suggest that intermarriage premiums are largely due to selection.
\end{abstract}

Keywords: Intermarriage, Intra-marriage, Income, Immigration, Assimilation, Gender JEL Codes: J12; J61; F22

\footnotetext{
${ }^{\uparrow}$ The author is grateful for comments from seminar participants at the $5^{\text {th }}$ Nordic Summer Institute in Labor Economics and the Stockholm University Linnaeus Center for Integration Studies (SULCIS).

* Lena Nekby, Department of Economics, Stockholm University, SULCIS and IZA Research Fellow, lena.nekby@ne.su.se.
} 


\section{Introduction}

A number of recent studies suggest that immigrant intermarriage with natives yields a positive causal effect on labor market outcomes such as income and employment (Meng and Gregory, 2005; Çelikaksoy, 2007; Meng and Meurs, 2009; Furtado and Theodoropoulos, 2009, 2010, Gevrek, 2009). ${ }^{1}$ Intermarriage with natives is assumed to have an assimilating role due to the enhancement of local human capital such a union creates in the form of improved knowledge about host country institutions, language and customs as well as access to native spouses' networks and contacts. The main problem with identifying a causal effect of intermarriage is that marriage choice is likely to be endogenous, unobserved factors influence both who we marry and labor market outcomes. This begs the question of whether it is possible to separate the effect of being assimilated in the labor market and subsequently intermarrying with natives from intermarrying with natives and becoming assimilated. The previous literature on intermarriage premiums is almost uniformly based on cross-section data, using instrumental variable methods to identify causal effects. ${ }^{2}$ In this study, panel data is used to assess intermarriage premiums for immigrants controlling for unobserved individual specific effects. Panel data also allows an analysis of income growth before and after marriage which can help to disentangle a causal effect of intermarriage on annual income from positive selection effects into intermarriage.

Focusing on the income effects of intermarriage, Meng and Gregory (2005), using OLS estimation on data from Australia, find that male immigrants intermarried to natives have 14.7 percent higher earnings than their single counterparts while male immigrants intra-married to other immigrants have 9.9 percent higher incomes. In other words, they find a 4.8 percentage

\footnotetext{
${ }^{1}$ Kantarevic (2004), however, finds no causal effect of intermarriage on earnings for the U.S. There is also a literature on the effects of intermarriage on children, see for example van Ours and Veenman (2008) and Furtado (2009).

${ }^{2}$ A recent exception is Nottmeyer (2010) who uses panel data to study intermarriage premiums in Germany.
} 
point relative intermarriage premium. For female immigrants the corresponding relative intermarriage premium was found to be 9.8 percentage points. Meng and Meurs (2009) find similar results for immigrants in France; immigrants that intermarry with natives earn 6 percent more than immigrants that intra-marry with other immigrants. The intermarriage premium increases considerably in both studies when the endogeneity of marriage choice is taken into account via instrument variable (IV) methods. Gevrek (2009) finds that intermarriage with a native is associated with a wage premium of 7 percent using Dutch data and IV estimation. ${ }^{3}$ These studies rely on two types of instruments; group size and sex ratios. Group size is defined as the size of the population (opposite sex) with similar characteristics, such as age, ethnicity, religion and/or region. Sex ratio is the proportion of the opposite sex with similar characteristics. ${ }^{4}$

An alternative strategy is to use panel data methods in order to eliminate individual (time invariant) unobserved heterogeneity. If marriage choice is as good as randomly assigned conditional on unobserved characteristics as well as (included in estimation) observable characteristics, a causal effect of intermarriage can be estimated. Nottmeyer (2010) estimates intermarriage premiums using panel data methods for Germany and finds no relative intermarriage premium. In other words, marriage premiums associated with marrying natives are found to be of similar magnitude to marriage premiums associated with marrying other immigrants. However, if important omitted variable are not time-invariant, than fixed effects estimation may not be enough to determine a causal effect of intermarriage on earnings. In

\footnotetext{
${ }^{3}$ Furtado and Theodoropoulos (2009, 2010) focus instead on employment effects using US data and find that marriage with a native increases employment probabilities.

4 There is a recent literature showing a causal effect of ethnic enclaves, measured as the size of the ethnic group, on labor market outcomes (Bertrand, et al., 2000;Damm, 2009; Edin, et al., 2003; Grönqvist, 2006; Åslund and Fredriksson, 2009), These studies suggest that the excludability of group size as an instrument for marriage may be questionable.
} 
such a case, selection into intermarriage on time varying unobservable characteristics may still bias fixed effects estimates of intermarriage premiums.

In order to get closer to determining a causal effect of intermarriage, the timing of marriage can instead be used in separate estimations by marriage type (intermarriage with natives/intramarriage with other immigrants). This setup implies that immigrants who intermarry in one year are compared to immigrants that do not intermarry that year but who do so at another point in the observation period (and likewise for those that intra-marry). Separate estimation by marriage type diminishes difficult sample selection effects. This so-called staggered treatment approach where treatment is defined as a change in civil status during a specific year, allows for an analysis of pre- and post treatment effects on income. If intermarriage alone, i.e., the change in civil status, has a causal effect on earnings, there should be no or smaller effects of intermarriage in the years prior to the actual year of marriage.

Although a change in civil status is an observable event, a causal effect of interacting with a native partner using the timing of marriage may nonetheless be difficult to identify, as the presumed mechanisms through which immigrants are thought to gain from intermarriage may benefit the individual before the actual year of marriage, i.e., during the courting stage or via a period of cohabitation. Immigrants may improve their host country language skills, enhance their knowledge of local institutions and benefit from the networks of native partners prior to the actual year of intermarriage. As such, the existence of pre-treatment effects on income does not alone refute a causal effect of interacting closely with natives on earnings. On the other hand, some benefits are likely to accrue to immigrants only after the actual date of marriage. Female immigrants for example may benefit from a change of surnames from 
foreign- to Swedish-sounding via intermarriage to natives. ${ }^{5}$ A lack of post-treatment effects would likewise suggest that it is not intermarriage per se that has an effect on income as one can safely assume that the benefits of intermarriage should accumulate and grow during the years close after marriage. A comparison of income growth around the year of marriage between marriage types can also shed some light on whether marriage to natives differs from marriage to other immigrants once selection into these marriage types is taken into account. As such, estimating and comparing the dynamics of a change in marital status on income can help us assess the plausibility that intermarriage has a causal impact on earnings and is not due to positive selection into this form of marriage.

In this study, marriage premiums are analyzed using panel data for the years 1998-2005. The sample used in estimation consists of four subsets of immigrants to Sweden, based on age at immigration and gender, who have a first registered change in civil status from single to married during the observation period. Three marriage types are defined for immigrants, intramarriage to spouses from the same country of origin, intra-marriage to spouses from other (non-Swedish) countries of origin and intermarriage to natives. Results from fixed effects estimation indicate positive marriage premiums for those that intra-marry with spouses from origin countries as well as those that intermarry with natives. Intra-marriage premiums associated with marriage to spouses from home countries are found to be of similar or significantly larger magnitude than premiums associated with intermarriage to natives. Results from staggered fixed effects estimation show that in comparison to those that have four or more years to marriage, income grows significantly prior to the year of marriage within each marriage type, indicating that a change in marital status per se does not have a

\footnotetext{
${ }^{5}$ See Arai and Skogman Thoursie (2009) for the causal effect of surname change (from foreign sounding to native sounding) on annual income.
} 
causal impact on earnings. A lack of post-marriage income growth for those that intermarry

with natives further puts into question a causal impact of intermarriage on income.

\section{Data and Empirical Setup}

\subsection{Data}

The data used in estimation stems from registered information at Statistics Sweden (SCB) on the entire foreign born population, 16-65 years of age, residing in Sweden during any of the years from 1998 to 2005. Included in the data is detailed individual information on personal and demographic characteristics, education, employment and income. ${ }^{6}$ Due to partner identification numbers, all individuals are linked to their partners if a partnership is registered during the year in question. Partnership is defined as marriage or cohabitation in a household with common children. ${ }^{7}$ As such, we have detailed information not only on the main individual but also on partners provided that partners fall under the given age restrictions. ${ }^{8}$ In addition, information on the full history of changes in civil status for all individuals in the sample is available including dates of civil status change.

The original sample of foreign born is broken down, by gender, into two sub-samples based on age at migration; immigration prior to the age of 16 and immigration between the ages of 16 and 45. This delineation is imposed in order to compare and contrast intermarriage rates and intermarriage premiums for immigrants that arrived young with those that arrived at older, but still marriageable ages. ${ }^{9}$ Three factors are generally thought to influence intermarriage rates: individual preferences, marriage market characteristics and third party

\footnotetext{
${ }^{6}$ The data (Statistics on Immigrants - STATIV) was initially created by the Swedish Integration Board.

${ }^{7}$ Data on partnerships stems from information on households. To date, Statistics Sweden tracks only married couples, couples in same-sex registered partnerships and cohabitants with children in common.

${ }^{8}$ Due to the age restrictions of the data, information on partners above the age of 65 is not available. It is possible to identify the civil status of those with older spouses due to registered information on civil status but no information on spousal characteristics is available.

${ }^{9}$ Only slightly more than 800 observations are lost due to the upper age at migration cut off (45).
} 
involvement (Angrist, 2002; Becker, 1974; Bisin and Verdier, 2000; Blau et al., 1982; Chiswick and Houseworth, 2008; Furtado, 2006; Jasso et al., 2000; Kalmijn, 1998; Kalmijn and Van Tubergen, 2006; Lievens, 1998, 1999; Schoen, 1983; Qian et al., 2001). Those who immigrated at a younger age may differ on all three dimensions due to assimilation effects associated with an early age at immigration (Böhlmark, 2008; Cahan et al., 2001; Cortes, 2006; Bonzalez, 2001; Schaafsma and Sweetman, 2001; van Ouers and Veenman, 2006). A younger age at migration may therefore imply greater access to native marriage and labor markets in comparison to those that arrived at older ages. In addition, those that arrive prior to the age of 16 are less likely to be tied movers or marriage migrants. ${ }^{10}$

The sample is restricted further to those aged 18 or over with a first change in civil status, from single to married, between 1999 and 2005 in order to have at least one observation on income prior to any change in civil status. As information on de facto marriages (cohabitation) is available only for those living in the same household with children in common, it is not possible to observe couples in de facto marriages before they have children. ${ }^{11}$ Couples in de facto marriages that never formally marry are therefore dropped from observation. ${ }^{12}$ After these restrictions, the sample used in estimation consists of 360,516 observations on foreign born individuals with a first change in civil status from single to married between the years 1999-2005. ${ }^{13}$

\footnotetext{
${ }^{10}$ Tied-movers are defined as immigrants that arrive in the host country to join earlier immigrated partners while marriage migrants are immigrants that immigrate for the primary purpose of marrying host country residents (native or immigrant).

${ }^{11}$ Statistics Sweden does not record information on cohabitants without children in common.

${ }^{12}$ Approximately 28 percent of the original sample is in de facto marriages (33 percent in the younger age at migration sub-sample and 25 percent in the older sub-sample).

${ }^{13}$ Note that a small proportion, $4.9 \%$ of those that eventually marry, indicate being in a de facto marriage with children prior to the formal change of civil status from single to married. For these individuals, year of marriage is defined by the observed year of a change in status from single to cohabitating. As a check of robustness, these individuals are also dropped from estimation with no change in results.
} 
Three types of marriages are defined for immigrants based on spouse's country of birth. Intra-marriage (National) is defined as a marriage to a foreign born person from the same country of origin. Intra-marriage (other Foreign Born) is defined as a marriage to a foreign born person from a different (non-Swedish) country of origin. Finally, intermarriage is defined as a marriage to a native born person.

Of those that marry, 47 percent of female immigrants and 33 percent of male immigrants intermarry with natives. ${ }^{14}$ This varies by age at migration, most notably in the older age at migration subsample where 47 percent of female immigrants but only 26 percent of male immigrants intermarry with natives. Of those that marry another foreign born spouse, 63-68 percent (female and male immigrants respectively) intra-marry with a person from the same country of origin. See Table 1 for intermarriage rates by region of origin.

Table 1: Intermarriage Rates, by Region of Origin

\begin{tabular}{|c|c|c|c|c|}
\hline & \multicolumn{2}{|c|}{ Age at Migration < 16} & \multicolumn{2}{|c|}{ Age at Migration 16-45 } \\
\hline & Female & Male & Female & Male \\
\hline & Immigrants & Immigrants & Immigrants & Immigrants \\
\hline Nordic & 80.9 & 76.6 & 63.4 & 51.4 \\
\hline West Europe & 74.3 & 69.0 & 67.1 & 70.5 \\
\hline East Europe & 27.2 & 32.2 & 32.5 & 13.8 \\
\hline \multicolumn{5}{|l|}{ North/Central } \\
\hline America & 71.5 & 77.3 & 80.8 & 72.3 \\
\hline South America & 58.0 & 60.1 & 61.2 & 33.4 \\
\hline Asia/Middle East & 42.7 & 32.6 & 41.5 & 9.1 \\
\hline African & 33.2 & 27.8 & 24.9 & 19.9 \\
\hline Oceania & 78.3 & 84.8 & 87.6 & 85.0 \\
\hline
\end{tabular}

The highest intermarriage rates are found among Nordic, West European and North/Central American immigrants as well as immigrants from Oceania and the lowest among East European, African and Asian immigrants. There are notable gender differences in

\footnotetext{
${ }^{14} 23$ percent of native born spouses are observed to have immigrant backgrounds, that is to at least one parent is foreign born. No delineation by so-called second generation status is done in this paper.
} 
intermarriage rates in the older age at migration sub-sample. Male immigrants from East Europe, South America, Asia and Africa indicate considerably lower intermarriage rates than their female counterparts. See also Table A1 in Appendix for intermarriage rates by country of origin for eight of the largest immigrant groups in Sweden.

\subsection{Empirical Setup}

For comparative purposes, pooled OLS estimation of the following general income equation is first estimated:

$$
\ln (\text { income })_{i t}=\beta_{1} M_{1 i t}+\beta_{2} M_{2 i t}+\beta_{3} M_{3 i t}+X_{i t}^{\prime} \gamma+\lambda_{t}+\varepsilon_{i t}
$$

where log income is the log of annual work earnings for individual $i$ during year $t{ }^{15}$ The main variables of interest $M_{1}, M_{2}$ and $M_{3}$ denote marriage to another foreign-born person from the same country of origin (intra-marriage: National), marriage to a foreign born person from another (non-Swedish) country of origin (intra-marriage: other Foreign Born) or marriage to a native born person (intermarriage) respectively. The reference group for $M_{1}, M_{2}$ and $M_{3}$ are those that are registered as single during the year in question. Note that the sample used in estimation is restricted to those that marry at some point during the observation period, reducing potential differences in income due to unobservable differences between those that never marry and those that eventually marry. $\mathrm{X}_{\mathrm{it}}$ is a vector of variables indicating both human capital and demographic variables such as age, education, region of origin, duration of residence and the presence of small children in the household. As data is pooled for the years 1998-2005, a full set of year dummies, $\lambda_{\mathrm{t}}$, are controlled for in estimation. Standard errors are clustered at the individual level in all estimations in order to account for individual serial correlation over time and any unknown form of heteroscedasticity.

\footnotetext{
${ }^{15}$ See Table A2 in Appendix for a description of variables used in estimation.
} 
If marriage choice is exogenously determined, estimation of equation (1) will yield causal estimates of intra- and intermarriage premiums on earnings. This is not likely to be the case; unobserved factors are likely to be correlated with respective type of marriage choice and earnings. The literature on positive assortative mating suggests that partnership formation is more likely to take place among individuals with similar characteristics in terms of for example, education, income, socioeconomic background, ethnicity, religion and religiosity as well as height, weight and IQ (Chiswick and Houseworth, 2008; Epstein and Guttman, 1984; Furtado, 2006; Lichter and Qian, 2001; Lieberson and Waters, 1988; Mare, 1991; Meng and Gregory, 2005, Sandefur and McKinnel, 1986; Schoen and Wooldredge, 1989; Pencavel, 1998; McPherson et al., 2001). These observed patterns of assortative mating suggest a correlation between marriage types and unobserved attributes such as language proficiency, motivation, social skills, ability and so forth. If marriage type is as good as randomly assigned conditional on unobserved time invariant attributes (such as social skills and ability) and other observed covariates, then a fixed effects model will yield causal estimates of marriage premiums. Fixed effects estimation of marriage premiums are therefore estimated based on the following general model:

$$
\ln (\text { income })_{i t}=\beta_{1} M_{1 i t}+\beta_{2} M_{2 i t}+\beta_{3} M_{3 i t}+X_{i t}^{\prime} \gamma+\lambda_{t}+\alpha_{i}+\varepsilon_{i t}
$$

The fixed effects model includes a full set of controls for individual effects, $\alpha_{\mathrm{i}}$, to account for individual heterogeneity and as earlier, a full set of year dummies $\left(\lambda_{t}\right)$ to account for changes in earnings over time common to all individuals. $\beta_{1}, \beta_{2}$ and $\beta_{3}$ measure the effect on earnings of a change in civil status from single to intra- or intermarried respectively. If cross-section estimates of marriage premiums are found to be higher than fixed effects estimates, this suggests a positive selection bias on cross-section estimates. Lower fixed effects estimates of 
marriage premiums may also in part be the result of accentuated measurement error in this type of estimation. This is especially the case when the status of interest is persistent over time and variation may be driven by errors in classification. Here, focus is explicitly on individuals who have a first change in marital status during the observation period, as such there is considerable variation in marital status. The data is also corrected for subsequent divorce, and marriage dates are corroborated with information on both civil status changes and partner information. Hence, the observed changes in marital status are unlikely to be driven primarily by noise as the scope for measurement error bias in estimation is small.

That the most important omitted variables are time-invariant may not, however, be true for this sample of relatively young immigrants entering into first marriages. Host language proficiency for example is likely to change over time and is important for both marriage choice and labor market outcomes. To further assess the existence of a causal effect of intermarriage on earnings, a staggered treatment approach, using the timing of marriage, is estimated separately for each marriage type. ${ }^{16}$ Estimation of the above models (equation 1 and 2) is based on individual marriage status in each year: single, intra-married or intermarried. The staggered treatment approach instead focuses exclusively on the year of marriage comparing the earnings of individuals that intermarry (intra-marry) in year t with those that do not intermarry (intra-marry) this year. This method diminishes sample selection issues under the assumption that time varying unobservable characteristics are relatively more similar within respective marriage type than across marriage types, especially with regards to characteristics of relevance for income. In other words, individuals that intermarry are presumed to be more alike in unobserved characteristics than those that intra-marry.

\footnotetext{
${ }^{16}$ The staggered treatment approach has been used in a number of earlier studies on different issues. See for example Bertrand and Mullainathan (1999), Stevenson and Wolfers (2006) and Arai and Skogman Thoursie (2009).
} 
This estimation strategy also allows for an assessment of pre- and post-marriage earnings growth which can indicate to what degree intermarriage (intra-marriage) premiums arise prior to the actual year of marriage. If changes in civil status alone have an effect on earnings, there should be no or small effects of marriage (either type) on earnings prior to the actual year of marriage. As a majority of those that marry interact with partners prior to the actual year of marriage, this method cannot rule out a causal effect of partnerships on income. Nonetheless, an effect of marriage on earnings in the years prior to the actual year of marriage suggests that those that are planning to intermarry (intra-marry) in the near future are on different income trajectories than those that have many years left to marriage. Following the model proposed by Arai and Skogman Thoursie (2009), the following equation is estimated separately for each type of marriage (intra- and intermarriage):

$$
\log \left(\text { income }_{i t}=\sum_{q=-2}^{3} \delta_{t+q} \text { YearOfMarriage } e_{i, t+q}+\delta_{t-3+} \text { YearOfMarriage }_{i, t-3+}+X_{i t}^{\prime} \gamma+\lambda_{t}+\alpha_{i}+\varepsilon_{i t}\right.
$$

YearOfMarriage denotes the year $t$ in which the individual $i$ intermarries with a native (alternatively intra-marries). Leads and lags of the year of marriage variable are dummy variables denoting whether or not intermarriage (intra-marriage) occurred in year $t+q$. The length of the panel data available allows for three leads where marriage occurs 1-3 years after the year $t$ and two lags where marriage occurs $1-2$ years before the year $t .{ }^{17}$ The variable YearOfMarriage $_{t-3+}$ is a dummy variable equal to one if the year of marriage occurred 3 or more years prior to the year $t$. This setup implies that there is a well-defined reference period covering four or more years prior to the actual year of marriage. All estimates of leads and lags of year of marriage are relative to this early reference period. For example, the coefficient

\footnotetext{
${ }^{17}$ As a change of marital status occurs during the years 1999-2005, an increase in the number of leads and lags implies that there are fewer and fewer individuals left to identify the effect of intermarriage. The trade off with using a lower number of leads is that there are fewer years to assess income trajectories prior to the actual year of intermarriage.
} 
for year $\mathrm{t}+3$ indicates the effect on earnings three years prior to intermarriage (intra-marriage) in comparison to those that have four or more years left to intermarriage (intra-marriage). Likewise, t-1 measures the effect on earnings one year after intermarriage (intra-marriage) in comparison to those that have four or more years left to intermarriage (intra-marriage). Note that the staggered treatment approach includes a full set of controls for individual effects, $\alpha_{\mathrm{i}}$, to control for the influence of time invariant unobservable characteristics on income.

Descriptive statistics by gender and marriage type are presented in Table 2. It is immediately clear that those that intermarry with natives differ from those that intra-marry with other immigrants (both types). Both pre- and post-marriage earnings as well as average employment rates are higher among those that intermarry in comparison with the two intra-marriage types. Average earnings and employment for those that intra-marry with spouses from other (nonSwedish) countries of origin born tend to lie between averages for those that intra-marry with spouses from home countries and those that intermarry with natives. Immigrants that intermarry with natives are somewhat older, have a longer duration of residence on average (as noted by year of immigration) and have considerably larger proportions with tertiary educations that those that intra-marry (especially among female immigrants). Finally, those that intermarry with natives are more likely to stem from Nordic and West European countries and less likely to stem from East European, Asian (especially male immigrants) and African countries.

Table 2: Descriptive Statistics, by Gender and Type of Marriage (Age at Migration: 0-45).

\begin{tabular}{lccc|ccc}
\hline & $\begin{array}{c}\text { Intra- } \\
\text { marriage: } \\
\text { National } \\
\text { Intra- }\end{array}$ & $\begin{array}{c}\text { Intemale } \\
\text { marriage: } \\
\text { Other F.B. }\end{array}$ & $\begin{array}{c}\text { Intives } \\
\text { Natiage: }\end{array}$ & $\begin{array}{c}\text { Male } \\
\text { Intra- } \\
\text { marriage: } \\
\text { National } \\
\text { Intra- }\end{array}$ & $\begin{array}{c}\text { Intermarriage: } \\
\text { marriage: } \\
\text { Other F.B. }\end{array}$ & $\begin{array}{c}\text { Natives } \\
\text { Pre-Marriage }\end{array}$ \\
$\begin{array}{l}\text { Earnings } \\
\begin{array}{l}\text { Post-Marriage } \\
\text { Earnings }\end{array}\end{array}$ & 1036 & 1304 & 1014 & 1240 & 1758 \\
Pre-Marriage & 38.8 & 45.9 & 63.4 & 1600 & 1799 & 2384 \\
\hline
\end{tabular}




\begin{tabular}{|c|c|c|c|c|c|c|}
\hline \multicolumn{7}{|l|}{ Employment } \\
\hline \multicolumn{7}{|l|}{ Employment } \\
\hline $\begin{array}{l}\text { Pre-Marriage Small } \\
\text { Child }\end{array}$ & 7.07 & 6.8 & 3.2 & 1.2 & 1.0 & 0.4 \\
\hline \multicolumn{6}{|l|}{ Small Child } & 54.8 \\
\hline Year of Birth & 1975 & 1975 & 1972 & 1971 & 1970 & 1970 \\
\hline $\begin{array}{l}\text { Year of } \\
\text { Immigration }\end{array}$ & 1993 & 1991 & 1988 & 1992 & 1990 & 1987 \\
\hline Age at Marriage & 26.2 & 27.4 & 30.1 & 30.9 & 32.1 & 31.7 \\
\hline \multicolumn{7}{|c|}{ Highest Level of Education (2005): } \\
\hline Short Compulsory & 7.0 & 4.6 & 4.3 & 9.0 & 6.9 & 2.4 \\
\hline Compulsory & 12.8 & 13.3 & 6.4 & 13.6 & 13.2 & 9.7 \\
\hline Secondary & 46.1 & 43.8 & 32.1 & 44.0 & 45.0 & 39.7 \\
\hline Short Tertiary & 5.3 & 7.0 & 6.2 & 4.5 & 5.4 & 6.9 \\
\hline Tertiary & 23.6 & 26.8 & 47.4 & 24.0 & 24.1 & 35.1 \\
\hline $\mathrm{PhD}$ & 1.1 & 1.6 & 2.2 & 2.2 & 2.5 & 3.5 \\
\hline Unknown & 4.1 & 2.9 & 1.5 & 2.8 & 3.0 & 2.7 \\
\hline \multicolumn{7}{|l|}{ Region of Origin: } \\
\hline Nordic & 7.8 & 10.5 & 25.9 & 5.4 & 10.3 & 27.8 \\
\hline West Europe & 2.5 & 5.7 & 9.8 & 1.6 & 8.8 & 19.9 \\
\hline East Europe & 32.2 & 31.7 & 14.7 & 27.1 & 25.0 & 13.2 \\
\hline North/Central & 0.5 & 2.1 & 4.0 & 0.4 & 2.2 & 5.0 \\
\hline \multicolumn{7}{|l|}{ America } \\
\hline South America & 4.7 & 8.4 & 9.2 & 2.7 & 5.5 & 7.3 \\
\hline Asia & 44.7 & 35.1 & 32.6 & 54.0 & 39.7 & 20.5 \\
\hline Africa & 7.6 & 6.3 & 3.0 & 8.8 & 8.1 & 4.4 \\
\hline Oceania & 0.04 & 0.3 & 0.7 & 0.02 & 0.5 & 2.0 \\
\hline $\begin{array}{l}\text { \# Observations } \\
\left(\mathrm{N}^{*} \mathrm{~T}\right)\end{array}$ & 53,994 & 31,722 & 81.182 & 88,810 & 41,730 & 63,078 \\
\hline
\end{tabular}

Note: Earnings are in 100 SEK and 2005 prices. Pre-marriage earnings are averaged over the years prior to marriage and post-marriage earnings are an averaged over the years after marriage (including year of marriage).

A comparison of post-marriage individual and spousal characteristics, by age at migration, is shown in Tables 3 and 4, for female and male immigrants respectively. It is immediately clear that those in the older age at migration sub-sample have a considerably shorter duration of residence on average than those in the younger age at migration sub-sample as seen by year of immigration. The older age at migration sub-sample is also somewhat older on average.

Spousal gaps in post-marriage income and employment are higher for female immigrants that intermarry compared to likewise gaps among those that intra-marry. This is especially noticeable for the younger age at migration sub-sample, where female immigrants have higher employment rates than their more recently arrived spouses. This is partially a consequence of longer duration of residence than spouses but also suggests a greater post-marriage 
employment attachment than, for example, female immigrants that marry natives. Spousal gaps in duration of residence are larger in the younger age at migration sub-sample suggesting that couples in the older age at migration sub-sample are to a larger degree tied-movers. Indeed, 21 percent of female immigrants in the older age at migration sub-sample have spouses that arrived in the host country within two years of their own year of immigration (39 percent among those that intra-marry with spouses from the same country of origin) compared to 9 percent in the younger sub-sample.

Table 3: Post Marriage Individual and Spousal Characteristics, Female Immigrants

\begin{tabular}{|c|c|c|c|c|c|c|}
\hline \multirow[b]{3}{*}{ Main Respondent } & \multicolumn{3}{|c|}{ Age at Migration $<16$} & \multicolumn{3}{|c|}{ Age at Migration 16-45 } \\
\hline & $\begin{array}{c}\text { Intra- } \\
\text { marriage: } \\
\text { National }\end{array}$ & $\begin{array}{c}\text { Intra- } \\
\text { marriage: } \\
\text { Other F.B. }\end{array}$ & $\begin{array}{c}\text { Intermarriage: } \\
\text { Natives }\end{array}$ & $\begin{array}{c}\text { Intra- } \\
\text { marriage: } \\
\text { National }\end{array}$ & $\begin{array}{c}\text { Intra- } \\
\text { marriage: } \\
\text { Other F.B. }\end{array}$ & $\begin{array}{c}\text { Intermarriage: } \\
\text { Natives }\end{array}$ \\
\hline & & & & & & \\
\hline Earnings & 1008 & 1142 & 1699 & 1063 & 1186 & 1450 \\
\hline Employment & 53.9 & 57.3 & 75.4 & 49.6 & 53.8 & 62.4 \\
\hline Year of Birth & 1979 & 1978 & 1973 & 1974 & 1973 & 1971 \\
\hline $\begin{array}{l}\text { Year of } \\
\text { Immigration }\end{array}$ & 1990 & 1986 & 1978 & 1996 & 1996 & 1997 \\
\hline \multicolumn{7}{|c|}{ Spouse (in parenthesis, difference to main respondent): } \\
\hline Earnings & $\begin{array}{l}1141 \\
(133)\end{array}$ & $\begin{array}{l}1422 \\
(280)\end{array}$ & $\begin{array}{c}2880 \\
(1181)\end{array}$ & $\begin{array}{l}1601 \\
(538)\end{array}$ & $\begin{array}{l}1846 \\
(660)\end{array}$ & $\begin{array}{c}3095 \\
(1645)\end{array}$ \\
\hline Employment & $\begin{array}{c}47.3 \\
(-6.6)\end{array}$ & $\begin{array}{c}53.1 \\
(-4.2)\end{array}$ & $\begin{array}{l}84.5 \\
(9.1)\end{array}$ & $\begin{array}{l}54.0 \\
(4.4)\end{array}$ & $\begin{array}{l}60.4 \\
(6.6)\end{array}$ & $\begin{array}{c}84.1 \\
(21.7)\end{array}$ \\
\hline Year of Birth & $\begin{array}{c}1975 \\
(-4)\end{array}$ & $\begin{array}{c}1973 \\
(-5)\end{array}$ & $\begin{array}{c}1970 \\
(-3)\end{array}$ & $\begin{array}{c}1969 \\
(-5)\end{array}$ & $\begin{array}{c}1967 \\
(-6)\end{array}$ & $\begin{array}{c}1965 \\
(-6)\end{array}$ \\
\hline $\begin{array}{l}\text { Year of } \\
\text { Immigration }\end{array}$ & $\begin{array}{c}1998 \\
(8)\end{array}$ & $\begin{array}{l}1996 \\
(10)\end{array}$ & -- & $\begin{array}{l}1997 \\
(1)\end{array}$ & $\begin{array}{c}1993 \\
(-3)\end{array}$ & -- \\
\hline $\begin{array}{l}\text { \# Observations } \\
\left(\mathrm{N}^{*} \mathrm{~T}\right)\end{array}$ & 24,453 & 16,788 & 42,557 & 29,541 & 14,934 & 38,625 \\
\hline
\end{tabular}

For male immigrants (Table 4), spousal income and employment gaps are, contrary to female immigrants, largest for those that intra-marry (either form) in comparison to those that intermarry. These differences in spousal gaps suggest different selection mechanisms into different forms of marriage by gender and age at migration. It also suggests that there may be differences in the labor market attachment of especially female immigrants depending on if 
they are bringing spouses from abroad after a longer period of time in the host country or are migrating to marry immigrants in Sweden. ${ }^{18}$

Table 4: Post Marriage Individual and Spousal Characteristics, Male Immigrants

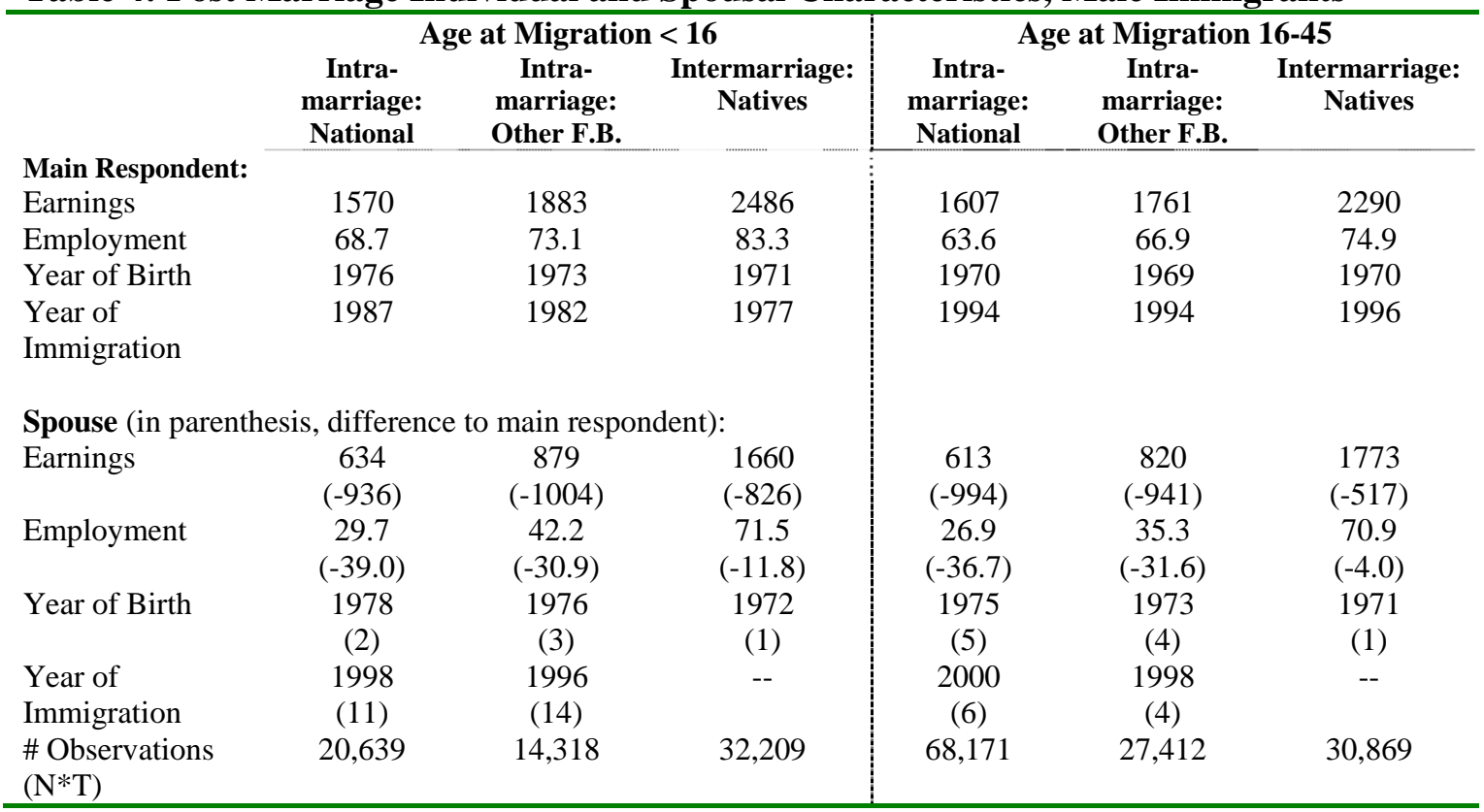

\section{Results: Marriage Premiums}

\subsection{OLS and Fixed Effects Estimation of Marriage Premiums on Income}

Results of pooled OLS and fixed effects estimation of marriage premiums are shown in Tables 5 and 6, for female and male immigrants respectively. Three models are estimated; OLS estimation of unadjusted marriage premiums (adjusted only for common time effects), OLS estimation of marriage premiums including controls for age, education, region of origin, duration of residence and the presence of small children in the household, and fixed effects estimation (including controls) of marriage premiums.

Table 5: Marriage Premiums on Earnings, Female Immigrants

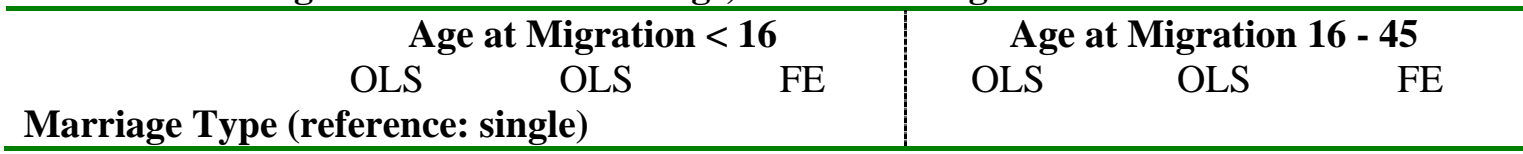

\footnotetext{
${ }^{18}$ Note that varying spousal selection by gender and age-at-migration implies that there is relatively little double counting across the male and female age-at-migration sub-samples.
} 


\begin{tabular}{|c|c|c|c|c|c|c|}
\hline $\begin{array}{l}\text { Intra-marriage } \\
\text { National }\end{array}$ & $\begin{array}{c}-0.154^{* *} \\
(0.019)\end{array}$ & $\begin{array}{c}0.103^{* *} \\
(0.017)\end{array}$ & $\begin{array}{c}0.083^{* *} \\
(0.019)\end{array}$ & $\begin{array}{c}-0.188^{* *} \\
(0.018)\end{array}$ & $\begin{array}{c}0.010 \\
(0.017)\end{array}$ & $\begin{array}{c}0.180 * * \\
(0.018)\end{array}$ \\
\hline $\begin{array}{l}\text { Intra-marriage } \\
\text { other foreign born }\end{array}$ & $\begin{array}{c}-0.032 \\
(0.021)\end{array}$ & $\begin{array}{l}0.045 * \\
(0.015)\end{array}$ & $\begin{array}{c}0.053 * * \\
(0.021)\end{array}$ & $\begin{array}{c}-0.103^{* *} \\
(0.024)\end{array}$ & $\begin{array}{c}0.005 \\
(0.021)\end{array}$ & $\begin{array}{c}0.091 * * \\
(0.024)\end{array}$ \\
\hline $\begin{array}{l}\text { Intermarriage } \\
\text { Natives }\end{array}$ & $\begin{array}{c}0.401 * * \\
(0.013)\end{array}$ & $\begin{array}{c}0.135 * * \\
(0.013)\end{array}$ & $\begin{array}{c}0.048 * * \\
(0.013)\end{array}$ & $\begin{array}{c}0.089 * * \\
(0.016)\end{array}$ & $\begin{array}{c}0.072 * * \\
(0.015)\end{array}$ & $\begin{array}{c}0.050 * * \\
(0.015)\end{array}$ \\
\hline Controls & No & Yes & Yes & No & Yes & Yes \\
\hline Observations & 70,258 & 70,258 & 70,258 & 61,878 & 61,878 & 61,878 \\
\hline R-squared & 0.06 & 0.26 & 0.57 & 0.02 & 0.22 & 0.59 \\
\hline \multicolumn{7}{|c|}{$\begin{array}{l}\text { Dependent variable: log annual earnings. Controls: All estimations include a full set of controls for year (1998- } \\
\text { 2005). Other controls are age ( } 5 \text { categories), education ( } 6 \text { categories), duration of residence (quadratic), a } \\
\text { dummy for the presence of small children in the household and region of origin ( } 8 \text { categories). ** denotes } \\
\text { significance at } 1 \% \text { level and * at } 5 \% \text { level. Standard Errors, in parenthesis, are clustered at the individual level in } \\
\text { all estimations. }\end{array}$} \\
\hline
\end{tabular}

Unadjusted premiums for intermarriage to natives are huge (Column 1). Female immigrants that intermarry with natives are associated with 40 percent higher earnings than single female immigrants (younger age at migration sub-sample) while female immigrant that intra-marry with a foreign born man from the same country of origin are associated with lower earnings than their single counterparts (15 percent lower). Female immigrants in the older age at migration subsample indicate a smaller intermarriage premium of 9 percent. For male immigrants intermarriage to natives is associated with 36-47 percent higher earnings, depending on sub-sample, while intra-marriage to a female immigrant from the same country of origin is associated with no or small marriage premiums (6 \% in the older age at migration sub-sample).

Much of this difference is explained by selection into respective marriage type. Controlling in OLS estimation for differences in human capital and demographic characteristics reduces premiums associated with intermarriage to natives considerably for both female and male immigrants (Column 2). For female immigrants, the relative intermarriage premium (relative 
to immigrants that marry spouses from the same country of origin) is reduced to 3.2 percentage points for the younger age at migration sub-sample and to 6.2 for the older age at migration sub-sample. Notice that intra-marriage (either type) is no longer associated with a marriage penalty.

For male immigrants the premium associated with intermarriage to a native is likewise reduced for both sub-samples. For male immigrants intermarriage is associated with 14 percent higher earnings in the younger age at migration sub-sample and with 9 percent higher earnings in the older sub-sample. Premiums associated with intra-marriage to spouses from the same country of origin are somewhat larger after controlling for observable characteristics. In the younger age at migration sub-sample the relative intermarriage premium, relative to intra-marriage with spouses from home countries, is 5.9 percentage points. These results are similar to the intermarriage premiums reported in Meng and Gregory (2005), Meng and Meurs (2009) and Gevrek (2009) for immigrants in Australia, France and Holland respectively.

Table 6: Marriage Premiums on Earnings, Male Immigrants

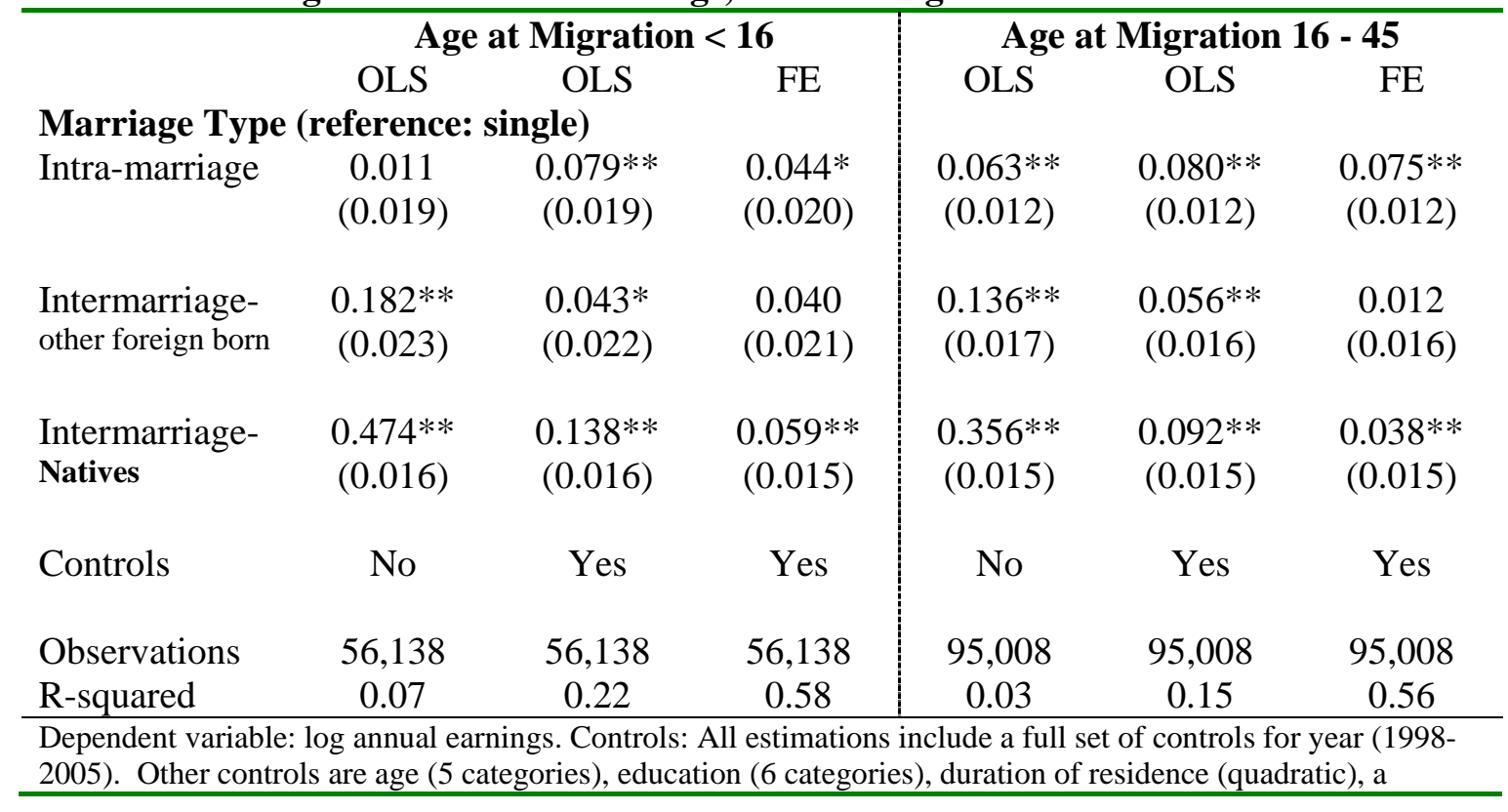


dummy for the presence of small children in the household and region of origin (8 categories). ${ }^{* *}$ denotes significance at $1 \%$ level and * at 5\% level. Standard Errors, in parenthesis, are clustered at the individual level in all estimations.

Estimation of marriage premiums via fixed effects estimation controlling for individual heterogeneity in unobserved time-invariant characteristics yields a very different picture of marriage premiums. A change in marital status from single to married with a native (intermarriage) continues to yield a significant income premium for both female and male immigrants but of smaller magnitude than in OLS estimation. Intra-marriage premiums are now found to be of similar or significantly larger magnitudes than intermarriage premiums, though no marriage premium is found for male immigrants that marry immigrants from other (non-Swedish) countries of origin. Note that female immigrants in the older age at migration sub-sample that intra-marry with spouses from home countries indicate an especially large intra-marriage premium. These results, similar to those found in Nottmeyer (2010) for Germany, suggest a positive selection bias on OLS estimates of intermarriage premiums as well as the existence of marriage premiums for both types of marriage (inter- and intramarriage) once unobserved heterogeneity is taken into account (again, with the exception of male immigrants that marry immigrants from other (non-Swedish) countries). ${ }^{19}$

There are some peculiarities in results by age at migration. One may have expected larger intermarriage premiums for immigrants with a higher age at migration due to the assumption of lower social and economic integration in comparison to those with younger ages at migration, all else equal, and therefore larger gains from interacting with natives or stronger positive selection effects into this type of marriage. This is not generally found to be true as

\footnotetext{
${ }^{19}$ Results for fixed effects estimation separately by region of origin (8 regions) are reported in Tables A3 and A4 for the younger and older age at migration sub-samples respectively. The large intra-marriage (national) premiums for female immigrants in the older age at migration sub-sample appear to be driven by relatively large marriage premiums for female immigrants from especially East Europe, but also from West Europe, Asia and Africa.
} 
intermarriage premiums are similar across sub-samples. Instead, those with an older age at migration, especially female immigrants, have higher intra-marriage premiums associated with marriage to spouses from home countries than those with a younger age at migration. Female immigrants also seem to benefit more from intra-marriage than their male counterparts.

These results suggest a higher relative female attachment to the labor market due to family investment type mechanisms where female immigrants remain attached to the labor market in order to assist their relatively more recently arrived immigrant spouses’ adjustment to the host country labor market. This is consistent with the small spousal employment gaps among female immigrants that intra-marry shown in Table 3. In the younger age at migration subsample, female immigrants that intermarry with other immigrants have higher employment rates, on average, post marriage than their spouses.

\subsection{Staggered Fixed Effects Estimation of Marriage Premiums on Income}

In order to analyze the dynamics of earnings growth before and after marriage, a staggered treatment approach is used based on variation in year of marriage. These estimations are done separately for each type of marriage (intra/inter) in order to further diminish difficult sample selection problems due to selection on time-varying unobservable characteristics such as host country language proficiency into respective marriage type.

Results for female immigrants are presented in Table 7. A comparison of the leads and lags to year of marriage for female immigrants indicates that there are significant increases in earnings prior to year of marriage for all three marriage types in comparison to those within respective marriage type that have four or more years to marriage. This indicates that a change in civil status per se does not have a causal impact on income. However, pre-marriage 
income growth does not in and of itself refute that interactions with a spouse-to-be has an effect on earnings as most partners meet 1-3 years prior to an actual change in civil status. Interestingly, relative earnings growth prior to marriage is largely similar for respective marriage type suggesting that female immigrants may have different marriage markets but that pre-marriage income growth is similar once selection into respective marriage type is accounted for.

Results in Table 7 also show that income growth appears to stabilize at a higher level around the year of marriage for those that intra-marry with spouses from home countries (intramarriage: national) or tapers off soon after marriage for the other two marriage types. Dougherty (2006) finds that marriage premiums for females in general peak about two years after marriage and decline thereafter. Results here therefore suggest that females that intramarry with men from home countries diverge from this general pattern as post-marriage income growth does not decline during the observation period but rather remains at a significantly higher level throughout the observation period, in comparison to the reference group. Note that a lack of post-marriage income growth for those that intermarry with natives further suggests that intermarriage premiums stem from unobserved selection into this type of marriage as one would otherwise expect earnings to continue escalating as immigrants reap the benefits of native networks, institutional know-how, language proficiency and so forth.

Table 7: Pre- and Post-Marriage Effects on Earnings, Female Immigrants. Staggered Fixed Effects Estimation Separately by Type of Marriage.

\begin{tabular}{lccc|ccc}
\hline & \multicolumn{3}{c|}{ Age at Migration < 16 } & \multicolumn{3}{c}{ Age at Migration 16-45 } \\
\hline & $\begin{array}{c}\text { Intra- } \\
\text { marriage } \\
\text { National }\end{array}$ & $\begin{array}{c}\text { Intra- } \\
\text { marriage } \\
\text { Other F.B. }\end{array}$ & $\begin{array}{c}\text { Intermarriage: } \\
\text { Natives }\end{array}$ & $\begin{array}{c}\text { Intra- } \\
\text { marriage } \\
\text { National }\end{array}$ & $\begin{array}{c}\text { Intra- } \\
\text { marriage } \\
\text { Other F.B. }\end{array}$ & $\begin{array}{c}\text { Intermarriage: } \\
\text { Natives }\end{array}$ \\
\hline 3 years before & 0.055 & 0.068 & $0.063^{* *}$ & $0.053^{*}$ & $0.058^{*}$ & $0.064^{* * *}$ \\
$\left(\delta_{\mathrm{t}+3}\right)$ & $(0.039)$ & $(0.043)$ & $(0.020)$ & $(0.029)$ & $(0.034)$ & $(0.015)$ \\
2 years before & $0.111^{*}$ & $0.132^{*}$ & $0.108^{* *}$ & $0.098^{* * *}$ & $0.105^{* *}$ & $0.110^{* * *}$ \\
$\left(\delta_{\mathrm{t}+2}\right)$ & $(0.053)$ & $(0.062)$ & $(0.027)$ & $(0.039)$ & $(0.047)$ & $(0.021)$ \\
1 year before & $0.170^{* *}$ & $0.179^{*}$ & $0.162^{* *}$ & $0.157 * * *$ & $0.143^{* *}$ & $0.159^{* * *}$ \\
\hline
\end{tabular}




\begin{tabular}{llll|ccc}
\hline$\left(\delta_{\mathrm{t}+1}\right)$ & $(0.053)$ & $(0.076)$ & $(0.034)$ & $(0.049)$ & $(0.059)$ & $(0.026)$ \\
Year of & $0.258^{* *}$ & $0.231^{* *}$ & $0.158^{* *}$ & $0.236^{* * *}$ & $0.196^{* * *}$ & $0.157 * * *$ \\
marriage $\left(\delta_{\mathrm{t}}\right)$ & $(0.081)$ & $(0.093)$ & $(0.042)$ & $(0.060)$ & $(0.072)$ & $(0.032)$ \\
1 year after $\left(\delta_{\mathrm{t}-}\right.$ & $0.288^{* *}$ & $0.230^{*}$ & $0.119^{*}$ & $0.233^{* * *}$ & $0.168^{* *}$ & $0.088^{* *}$ \\
$1)$ & $(0.096)$ & $(0.093)$ & $(0.050)$ & $(0.071)$ & $(0.086)$ & $(0.038)$ \\
2 years after & $0.248^{*}$ & 0.184 & 0.083 & $0.200^{* *}$ & 0.122 & 0.059 \\
$\left(\delta_{\mathrm{t}-2}\right)$ & $(0.113)$ & $(0.131)$ & $(0.058)$ & $(0.083)$ & $(0.102)$ & $(0.045)$ \\
3 or more years & $0.271 *$ & 0.174 & 0.052 & $0.203^{* *}$ & 0.101 & 0.036 \\
after $\left(\delta_{\mathrm{t}-3}\right)$ & $(0.134)$ & $(0.154)$ & $(0.069)$ & $(0.099)$ & $(0.121)$ & $(0.053)$ \\
Observations & 18,288 & 13,185 & 38,845 & 31,219 & 20,802 & 65,963 \\
(Individuals) & $(3,437)$ & $(2,331)$ & $(5,444)$ & $(5,789)$ & $(3,605)$ & $(9,285)$ \\
\hline
\end{tabular}

Staggered fixed effects estimation of marriage premiums for male immigrants indicate similar patterns to female immigrants with the exception of intra-marriage to other foreign born spouses where no significant changes in income either prior to or after the actual year of marriage are noted. Similar to female immigrants, there is significant pre-marriage income growth for those that intra-marry with spouses from the same country of origin as well as for those that intermarry with natives. Unlike female immigrants, pre-marriage income growth is stronger for those that intra-marry in comparison to those that intermarry suggesting that once selection is taken into account, intra-marriage to spouses from the same country of origin is associated with stronger income growth than intermarriage to natives. This is also seen by the continued significantly higher level of income post-marriage for those that intra-marry with spouses from home countries.

Table 8: Pre- and Post-Marriage Effects on Earnings, Male Immigrants. Staggered Fixed Effects Estimation Separately by Type of Marriage.

\begin{tabular}{lccc|ccc}
\hline & \multicolumn{3}{c|}{ Age at Migration $<16$} & \multicolumn{3}{c}{ Age at Migration 16-45 } \\
\hline & $\begin{array}{c}\text { Intra- } \\
\text { marriage } \\
\text { National }\end{array}$ & $\begin{array}{c}\text { Intra- } \\
\text { marriage } \\
\text { Other F.B. }\end{array}$ & $\begin{array}{c}\text { Intermarriage: } \\
\text { Natives }\end{array}$ & $\begin{array}{c}\text { Intra- } \\
\text { marriage } \\
\text { National }\end{array}$ & $\begin{array}{c}\text { Intra- } \\
\text { marriage } \\
\text { Other F.B. }\end{array}$ & $\begin{array}{c}\text { Intermarriage: } \\
\text { Natives }\end{array}$ \\
\hline 3 years before & $0.103^{* *}$ & 0.035 & $0.047^{*}$ & $0.091^{* * *}$ & 0.019 & $0.035^{* *}$ \\
$\left(\delta_{\mathrm{t}+3}\right)$ & $(0.038)$ & $(0.040)$ & $(0.023)$ & $(0.027)$ & $(0.031)$ & $(0.016)$ \\
2 years before & $0.164^{* *}$ & 0.021 & $0.080^{* *}$ & $0.133^{* * *}$ & 0.002 & $0.056^{* * *}$ \\
$\left(\delta_{\mathrm{t}+2}\right)$ & $(0.053)$ & $(0.054)$ & $(0.031)$ & $(0.038)$ & $(0.042)$ & $(0.021)$ \\
1 year before & $0.227^{* *}$ & 0.063 & $0.101^{* *}$ & $0.185^{* * *}$ & 0.026 & $0.062^{* *}$ \\
$\left(\delta_{\mathrm{t}+1}\right)$ & $(0.068)$ & $(0.069)$ & $(0.038)$ & $(0.048)$ & $(0.053)$ & $(0.027)$ \\
Year of & $0.256^{* *}$ & 0.074 & $0.100^{*}$ & $0.198^{* * *}$ & 0.034 & $0.058^{*}$ \\
\hline
\end{tabular}




\begin{tabular}{llll|ccc}
\hline marriage $\left(\delta_{\mathrm{t}}\right)$ & $(0.068)$ & $(0.085)$ & $(0.047)$ & $(0.059)$ & $(0.066)$ & $(0.034)$ \\
1 year after $\left(\delta_{\mathrm{t}-}\right.$ & $0.287 * *$ & 0.081 & 0.096 & $0.207 * * *$ & 0.017 & 0.049 \\
$1)$ & $(0.100)$ & $(0.102)$ & $(0.056)$ & $(0.071)$ & $(0.080)$ & $(0.040)$ \\
2 years after & $0.290^{* *}$ & 0.026 & 0.057 & $0.197 * *$ & -0.038 & 0.006 \\
$\left(\delta_{\mathrm{t}-2}\right)$ & $(0.118)$ & $(0.118)$ & $(0.066)$ & $(0.083)$ & $(0.093)$ & $(0.047)$ \\
3 or more years & $0.288^{*}$ & -0.038 & 0.043 & $0.175 *$ & -0.088 & -0.038 \\
after $\left(\delta_{\mathrm{t}-3}\right)$ & $(0.140)$ & $(0.141)$ & $(0.078)$ & $(0.099)$ & $(0.112)$ & $(0.055)$ \\
Observations & 15,809 & 11,578 & 28,751 & 30,316 & 19,102 & 59,178 \\
(Individuals) & $(2,657)$ & $(1,817)$ & $(4,044)$ & $(5,107)$ & $(3,031)$ & $(8,481)$ \\
\hline
\end{tabular}

Descriptive statistics on spousal labor market gaps presented in Table 3 and 4 show that female immigrants that marry male immigrants, on average, have higher or similar postmarriage employment rates than their more recently arrived immigrant spouses. This is not true for female immigrants that marry male natives where the spousal employment gap is negative (native husbands have higher employment rates than their immigrant wives). Similar patterns are found for male immigrants where employment gaps to spouses are considerably larger for those that marry female immigrants relative to those that marry female natives. Mechanisms akin to the so-called family investment hypotheses (Baker and Benjamin, 1997; Duleep and Sanders, 1993) may be at work where spouses with higher duration of residence, regardless of gender, maintain a higher relative attachment to the labor market in order to assist the labor market transition of more recently-arrived spouses.

\subsection{Fixed Effects Estimation of Marriage Premiums on Employment}

In order to determine to what degree observed marriage premiums on income accrue from the extensive or intensive margin, i.e., from higher employment rates or more hours, staggered fixed effects estimates of employment are estimated for each type of marriage. Results for female immigrants, shown in Table 9, show some pre-marriage employment growth but little 
post marriage employment growth with the exception of female immigrants in the older age at migration sub-sample that marry natives.

Table 9: Pre- and Post-Marriage Effects on Employment, Female Immigrants. Staggered Fixed Effects Estimation Separately by Type of Marriage.

\begin{tabular}{|c|c|c|c|c|c|c|}
\hline & \multicolumn{3}{|c|}{ Age at Migration $<16$} & \multicolumn{3}{|c|}{ Age at Migration 16-45 } \\
\hline & $\begin{array}{l}\text { Intra- } \\
\text { marriage } \\
\text { National }\end{array}$ & $\begin{array}{c}\text { Intra- } \\
\text { marriage } \\
\text { Other F.B. }\end{array}$ & $\begin{array}{c}\text { Intermarriage: } \\
\text { Natives }\end{array}$ & $\begin{array}{c}\text { Intra- } \\
\text { marriage } \\
\text { National }\end{array}$ & $\begin{array}{c}\text { Intra- } \\
\text { marriage } \\
\text { Other F.B. }\end{array}$ & $\begin{array}{c}\text { Intermarriage: } \\
\text { Natives }\end{array}$ \\
\hline 3 years before & 0.022 & $0.043 * *$ & $0.020 *$ & 0.015 & -0.015 & $0.056 * *$ \\
\hline$\left(\delta_{t+3}\right)$ & $(0.015)$ & $(0.018)$ & $(0.010)$ & $(0.014)$ & $(0.020)$ & $(0.014)$ \\
\hline 2 years before & 0.039 & $0.078 * *$ & $0.042 * *$ & 0.036 & 0.017 & $0.083 * *$ \\
\hline$\left(\delta_{t+2}\right)$ & $(0.020)$ & $(0.025)$ & $(0.013)$ & $(0.019)$ & $(0.026)$ & $(0.017)$ \\
\hline 1 year before & $0.056^{*}$ & $0.084 * *$ & $0.046 * *$ & 0.041 & 0.026 & $0.108 * *$ \\
\hline$\left(\delta_{t+1}\right)$ & $(0.026)$ & $(0.031)$ & $(0.016)$ & $(0.024)$ & $(0.033)$ & $(0.021)$ \\
\hline Year of & 0.052 & $0.085^{*}$ & 0.010 & $0.066^{*}$ & 0.042 & $0.135 * *$ \\
\hline marriage $\left(\delta_{t}\right)$ & $(0.031)$ & $(0.037)$ & $(0.020)$ & $(0.029)$ & $(0.040)$ & $(0.024)$ \\
\hline 1 year after $\left(\delta_{t-}\right.$ & 0.046 & 0.077 & 0.003 & 0.053 & 0.013 & $0.147 * *$ \\
\hline 1) & $(0.038)$ & $(0.045)$ & $(0.024)$ & $(0.034)$ & $(0.048)$ & $(0.029)$ \\
\hline 2 years after & 0.043 & 0.088 & 0.001 & 0.042 & 0.008 & $0.156 * *$ \\
\hline$\left(\delta_{\mathrm{t}-2}\right)$ & $(0.044)$ & $(0.053)$ & $(0.029)$ & $(0.040)$ & $(0.056)$ & $(0.034)$ \\
\hline 3 or more years & 0.061 & 0.063 & -0.001 & 0.044 & 0.013 & $0.167 * *$ \\
\hline after $\left(\delta_{t-3}\right)$ & $(0.053)$ & $(0.063)$ & $(0.034)$ & $(0.048)$ & $(0.066)$ & $(0.040)$ \\
\hline Observations & 24,452 & 16,788 & 42,557 & 29,541 & 14,934 & 38,625 \\
\hline (Individuals) & $(3,583)$ & $(2,399)$ & $(5,486)$ & $(4,590)$ & $(2,338)$ & $(6,237)$ \\
\hline \multicolumn{7}{|c|}{$\begin{array}{l}\text { Dependent variable: employment status (0/1). Controls: age (5 categories), education ( } 7 \text { categories), duration of } \\
\text { residence (quadratic), small children (dummy), year dummies }(1998-2005) . * * \text { denotes significance at } 1 \% \text { level } \\
\text { and * significance at } 5 \% \text { level. Standard Errors, in parenthesis, are clustered at the individual level in all } \\
\text { estimations. }\end{array}$} \\
\hline
\end{tabular}

Even for male immigrants, significant employment growth, relative to those that have four years or more to marriage, both pre- and post-marriage is noted for those that marry natives in the older age at migration sub-sample. Employment stabilizes at a level approximately 9 percentage points higher at the year of marriage relative to those within this marriage type, that have four or more years left to marriage.

After controlling for individual heterogeneity, immigrants that intra-marry with spouses from home countries do not indicate significant employment changes around the year of marriage. Significantly higher levels of income post-marriage, noted above, must therefore stem from changes in work hours or wages rather than changes in employment. 
Table 10: Pre- and Post-Marriage Effects on Employment, Male Immigrants Staggered Fixed Effects Estimation Separately by Type of Marriage.

\begin{tabular}{|c|c|c|c|c|c|c|}
\hline & \multicolumn{3}{|c|}{ Age at Migration < 16} & \multicolumn{3}{|c|}{ Age at Migration 16-45 } \\
\hline & $\begin{array}{l}\text { Intra- } \\
\text { marriage } \\
\text { National }\end{array}$ & $\begin{array}{l}\text { Intra- } \\
\text { marriage } \\
\text { Other F.B. }\end{array}$ & $\begin{array}{c}\text { Intermarriage: } \\
\text { Natives }\end{array}$ & $\begin{array}{l}\text { Intra- } \\
\text { marriage } \\
\text { National }\end{array}$ & $\begin{array}{l}\text { Intra- } \\
\text { marriage } \\
\text { Other F.B. }\end{array}$ & $\begin{array}{c}\text { Intermarriage: } \\
\text { Natives }\end{array}$ \\
\hline 3 years before & 0.028 & 0.006 & 0.010 & $0.033 * *$ & $0.038 * *$ & 0.016 \\
\hline$\left(\delta_{t+3}\right)$ & $(0.015)$ & $(0.017)$ & $(0.012)$ & $(0.009)$ & $(0.014)$ & $(0.014)$ \\
\hline 2 years before & $0.046^{*}$ & -0.007 & 0.011 & $0.047 * *$ & $0.041^{*}$ & $0.038^{*}$ \\
\hline$\left(\delta_{\mathrm{t}+2}\right)$ & $(0.021)$ & $(0.023)$ & $(0.014)$ & $(0.011)$ & $(0.018)$ & $(0.017)$ \\
\hline 1 year before & $0.072 * *$ & 0.006 & 0.021 & $0.046 * *$ & $0.044^{*}$ & $0.061 * *$ \\
\hline$\left(\delta_{t+1}\right)$ & $(0.026)$ & $(0.029)$ & $(0.017)$ & $(0.014)$ & $(0.023)$ & $(0.021)$ \\
\hline Year of & $0.082 * *$ & 0.003 & 0.017 & $0.041 *$ & 0.042 & $0.089 * *$ \\
\hline marriage $\left(\delta_{t}\right)$ & $(0.032)$ & $(0.034)$ & $(0.021)$ & $(0.017)$ & $(0.027)$ & $(0.025)$ \\
\hline 1 year after $\left(\delta_{\mathrm{t}-}\right.$ & $0.082 *$ & -0.005 & 0.010 & 0.034 & 0.042 & $0.101^{* *}$ \\
\hline & $(0.032)$ & $(0.041)$ & $(0.025)$ & $(0.021)$ & $(0.033)$ & $(0.030)$ \\
\hline 2 years after & 0.083 & -0.034 & -0.011 & 0.029 & 0.039 & $0.092 * *$ \\
\hline$\left(\delta_{t-2}\right)$ & $(0.045)$ & $(0.048)$ & $(0.030)$ & $(0.024)$ & $(0.038)$ & $(0.035)$ \\
\hline 3 or more years & 0.065 & -0.076 & -0.032 & 0.015 & 0.022 & $0.091 * *$ \\
\hline after $\left(\delta_{t-3}\right)$ & $(0.054)$ & (0.059) & $(0.035)$ & $(0.010)$ & $(0.046)$ & $(0.041)$ \\
\hline Observations & 20,639 & 14,318 & 32,209 & 68,171 & 27,412 & 30,869 \\
\hline (Individuals) & $(2,758)$ & $(1,882)$ & $(4,624)$ & $(9,625)$ & $(3,912)$ & $(4,775)$ \\
\hline \multicolumn{7}{|c|}{$\begin{array}{l}\text { Dependent variable: employment status (0/1). Controls: age (5 categories), education ( } 7 \text { categories), duration of } \\
\text { residence (quadratic), small children (dummy), year dummies }(1998-2005) . * * \text { denotes significance at } 1 \% \text { level } \\
\text { and * significance at } 5 \% \text { level. Standard Errors, in parenthesis, are clustered at the individual level in all } \\
\text { estimations. }\end{array}$} \\
\hline
\end{tabular}

\section{Conclusions}

In this study, inter- and intra-marriage premiums are analyzed using panel data for the years 1998-2005. The sample used in estimation consists of two subsets of immigrants in Sweden, based on age at immigration, who have a first registered change in civil status from single to married during the observation period. Three marriage types are defined, intra-marriage to spouses from the same country of origin, intra-marriage to spouses from other (non-Swedish) countries of origin and intermarriage to natives. Results from fixed effects estimation indicate positive marriage premiums for both types of intra- and inter-marriage, with the exception of male immigrants that intra-marry with spouses from other (non-Swedish) countries of origin. Intra-marriage premiums associated with marriage to spouses from home countries are found to be of similar or significantly larger magnitude than premiums associated with intermarriage to natives. 
As selection based on unobserved time-varying characteristics, such as host language proficiency, may still bias estimates of marriage premiums, staggered fixed effects models of income, using variation in the timing of marriage, are estimated separately for each type of marriage. If one believes that unobservable characteristics are more similar within marriage types than across marriage types, this type of estimation further reduces any remaining selection bias on coefficient estimates. Results indicate that there are significant increases in earnings prior to year of marriage for all three marriage types in comparison to those within respective marriage type that have four or more years to marriage. As such, there is no causal impact of a change in civil status per se on earnings. This result does not, however, refute that interactions with natives prior to intermarriage has a causal effect on earnings. A lack of postmarriage earnings growth for those that intermarry with natives, however, does as one would expect earnings growth to escalate shortly after marriage when immigrants reap the benefits of the networks, institutional know-how, language proficiency and other factors associated with having a native spouse.

Results presented here suggest that intra-marriage to spouses from home countries is associated with a stronger relative attachment to the labor market, once selection into this type of marriage is accounted for, as earnings do not appear to taper off post-marriage (during the observation period) as is found for those that intermarry with natives. This patterns suggest that there may be mechanisms at work pushing immigrants to maintain a stronger relative attachment to the labor market in order to help more recently-arrived spouses enter the labor market, and is consistent with results showing smaller spousal employment gaps postmarriage for those that intra-marry than those that intermarry. 
In conclusion, marriage is associated with higher income for both female and male immigrants in Sweden, regardless of marriage type (with one exception), once selection based on unobserved time invariant heterogeneity is taken into account. Significant earnings growth prior to the actual year of marriage combined with a lack of income growth post-marriage suggest that the premiums associated with intermarriage to natives found in earlier studies are, at least in the Swedish context, largely due to unobserved selection. 


\section{References:}

Angrist, J., (2002) "How do Sex Ratios Affect Marriage and Labour Markets? Evidence from America’s Second Generation”, Quarterly Journal of Economics, 117(3): 997-1038.

Baker, M. and Benjamin, D. (1997), “The role of the Family in Immigrants’ Labor Market Activity: An Evaluation of Alternative Explanations" American Economic Review, Vol. 87(4): 705-27.

Becker, G. S., (1974) A Theory of Marriage, Economics of the Family, Chicago/London: University of Chicago Press 299-344.

Bertrand, M., E. Luttmer, and S. Mullainathan (2000), "Network Effects and Welfare Cultures”, Quarterly Journal of Economics CXV, 1019-1055.

Bertrand, M. and S. Mullainathan (1999), "Is there Discretion in Wage Setting?”, Rand Journal of Economics, Vol. 30(3): 535-54.

Bisin, A. and Verdier, T., (2000) "Beyond the Melting Pot: Cultural Transmission, Marriage and the Evolution of Ethnic and Religious Traits”, Quarterly Journal of Economics, Vol. 115: 955-988.

Blau, P. M., Blum, T. C. and Schwartz, J. E., (1982) "Heterogeneity and Intermarriage" American Sociological Review 47: 45-62.

Böhlmark, A., (2008), ”Age at Immigration and School Performance: A Siblings Analysis using Swedish Register Data” Labour Economics, Vol 15(6): 1366-1387.

Cahan S., Davis, D. And Staub,R., (2001) ”Age at Immigration and Scholastic Achievement in School-Age Children: Is There A Vulnerable Age?”, International Migration Review Vol. 35 (2), pp. 587-595.

Çelikaksoy, A. (2007), “A Wage Premium or Penalty: An Analysis of Endogamous Marriage Effects among the Children of Immigrants?”, Danish Journal of Economics (Nationaløkonomisk Tidsskrift), 145 (3): 288-311.

Chiswick B. and C. Houseworth (2008), "Ethnic Intermarriage among Immigrants: Human Capital and Assortative Mating”, IZA DP No. 3740

Cortes, K.E. (2006), ”The Effects of Age at Arrival and Enclave Schools on the Academic Performance of Immigrant Children”, Economics of Education Review Vol. 25 (2), pp. 121132

Damm, A.P. (2009), "Ethnic Enclaves and Immigrant Labor Market Outcomes: QuasiExperimental Evidence”. Journal of Labor Economics, 27(2): 281-314.

Duleep, H.O. and Sanders, S. (1993), “The Decision to Work by Married Immigrant Women” Industrial and Labor Relations Review, Vol. 46(4): 677-690. 
Edin P-A, P Fredriksson \& O Åslund (2003) "Ethnic enclaves and the economic success of immigrants: evidence from a natural experiment”, Quarterly Journal of Economics, 118: 329-357.

Epstein, E. and Guttman, R., (1984) "Mate Selection in Man: Evidence, Theory and Outcome”, Social Biology, 31(4), 243-278.

Furtado D. (2006) “Human Capital and Interethnic Marriage Decisions”. IZA Discussion Paper Series No. 1989.

Furtado, D., (2009), “Cross Nativity Marriage and Human Capital Levels of Children” in Professor Solomon Polachek, Dr Konstantinos Tatsiramos (ed.) Ethnicity and Labor Market Outcomes (Research in Labor Economics, Volume 29), Emerald Group Publishing Limited, pp.273-296

Furtado, D. and Theodoropoulos, N., (2009), "I’ll Marry You if You Get Me a Job: Marital Assimilation and Immigrant Employment Rates” International Journal of Manpower, Vol. 30(1/2): 116-126.

Furtado, D. and Theodoropoulos, N., (2010), "Why Does Intermarriage Increase Immigrant Employment? The Role of Networks” IZA Discussion Paper No. 5080.

Gevrek, Z.E., (2009), “Interethnic Marriage and the Labor Market Integration of Immigrants”, Department of Economics, University of Arizona.

Gonzalez, A., (2001), ”The education and wages of immigrant children: the impact of age at arrival”, Economics of Education Review Vol. 22, pp. 203-212.

Grönqvist Hans (2006), "Ethnic Enclaves and the Attainments of Immigrant Children", European Sociological Review, 22(4):369-382.

Jasso, G., Massey, D. S., Rosenaweig, M. R. and Smith, J. P., (2000) “Assortative Mating among Married New Legal Immigrants to the United States: Evidence from the New Immigrant Survey Pilot” International Migration Review, 34(2):443-459.

Kalmijn, M., (1998), “Intermarriage and homogamy:Causes, patterns, trends”, Annual Review of Sociology, 24: 395-421.

Kalmijn, M and Van Tubergen, F., (2006) “ Ethnic intermarriage in the Netherlands: confirmations and refutations of accepted insights”, European Journal of Population, 22:371397.

Kantarevic, J. (2004), “Interethnic Marriages and Economic Assimilation of Immigrants” IZA Discussion Paper Series No. 1142, Bonn.

Lichter, D. T. and Z. Qian (2001) "Measuring Marital Assimilation: Intermarriage Among Natives and Immigrants”, Social Science Research 30:289-312.

Lieberson, S. and M. Waters (1988), From Many Strands: Ethnic and Racial Groups in Contemporary America. New York: Russell Sage Foundation. 
Lievens, J., (1998) "Interethnic marriage: Bringing in the context through multilevel modelling.”, European Journal of Population, 14:117-155.

Lievens, J., (1999) "Family-Forming Migration from Turkey and Morocco to Belgium: The demand for Marriage Partners from the Countries of Origin”, The International Migration Review, 33(3): 717-744.

Mare, R. D., (1991) "Five Decades of Educational Assortative Mating” American Sociological Review 56:15-32.

McPherson, M., Smith-Lovin, L. and Cook, J. M., (2001) Birds of a feather: Homophily in social networks”, Annual Review of Sociology, 24: 415-444.

Meng, X., and Gregory, R. R., (2005) "Intermarriage and the Economic Assimilation of Immigrants, Journal of Labor Economics 23: 135-175.

Meng, X. and Meurs, D. (2006) "Intermarriage, Language and the Economic Assimilation Process: A Case Study of France”, International Journal of Manpower, 30(12):127-144.

Sandefur G.D. and T. McKinnell, (1986), “American Indian Intermarriage”, Social Science Research , 347 pp. 347-48.

Schaafsma, J. and Sweetman, A., (2001), ”Immigrant earnings; age at immigration matters”, Canadian Journal of Economics Vol. 34, pp. 1066-1099.

Schoen, R. and J. Wooldredge, (1989), "Marriage Choices in North Carolina and Virginia, 1969-1971 and 1979-1981”, Journal of Marriage and the Family, 51: pp. 465-481.

Skogman Thoursie, P. and Arai, A., (2009), "Renouncing Personal Names: An Empirical Examination of Surname Change and Earnings" Journal of Labor Economics, Vol. 27(1): 127-147.

Stevenson, B. and Wolfers, J., (2006), "Bargaining in the Shadow of the Law: Divorece Laws and Family Distress”, Quarterly Journal of Economics, Vol. 121(1):267-88.

Pencavel, J., (1998) "Assortative Mating by Schooling and the Work Behavior of Wives and Husbands” American Economic Review 88(2):326-329.

Qian, Z.; Blair, S. L.; and Ruf, S. D., (2001) “Asian American interracial and interethnic marriages: Differences by Education and nativity”, International Migration Review, 35: 557586.

Schoen, R., (1983) "Measuring the Tightness of the Marriage Squeeze.” Demography 20:6278.

Van Ours, J.C. and Veenman, J., (2006), ”Age at Immigration and Educational Attainment of Young Immigrants”, Economics Letters Vol. 90 (3), pp. 310-316. 
Åslund O \& P Fredriksson (2009) "Peer effects in welfare dependence--Quasi-experimental evidence", Journal of Human Resources, 44(3): 798-825. 


\section{Appendix}

Table A1: Intermarriage Rates by Country of Origin

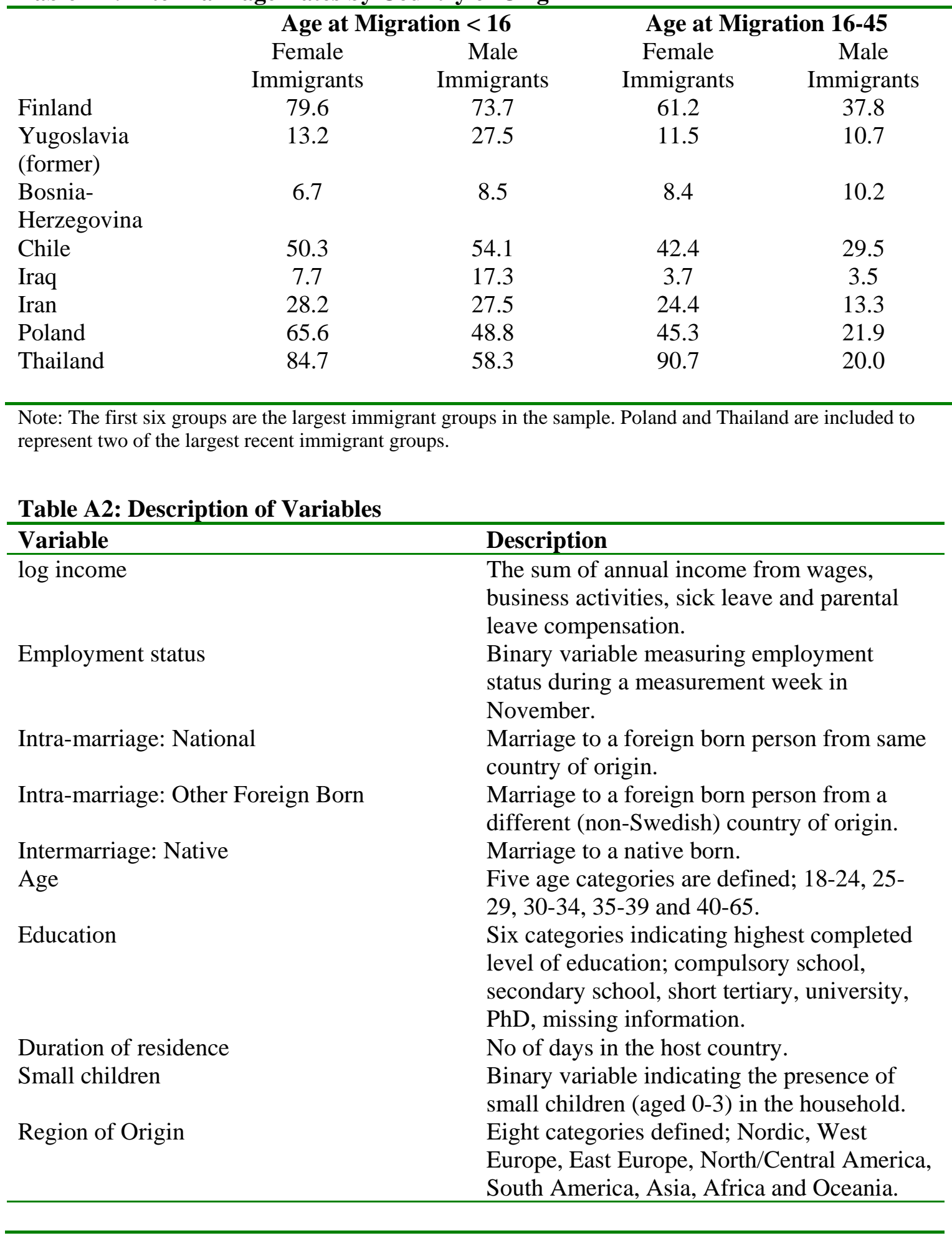


Table A3: Marriage Premiums on Earnings, by Gender and Region of Origin, Age at Migration < 16. Fixed Effects Estimation

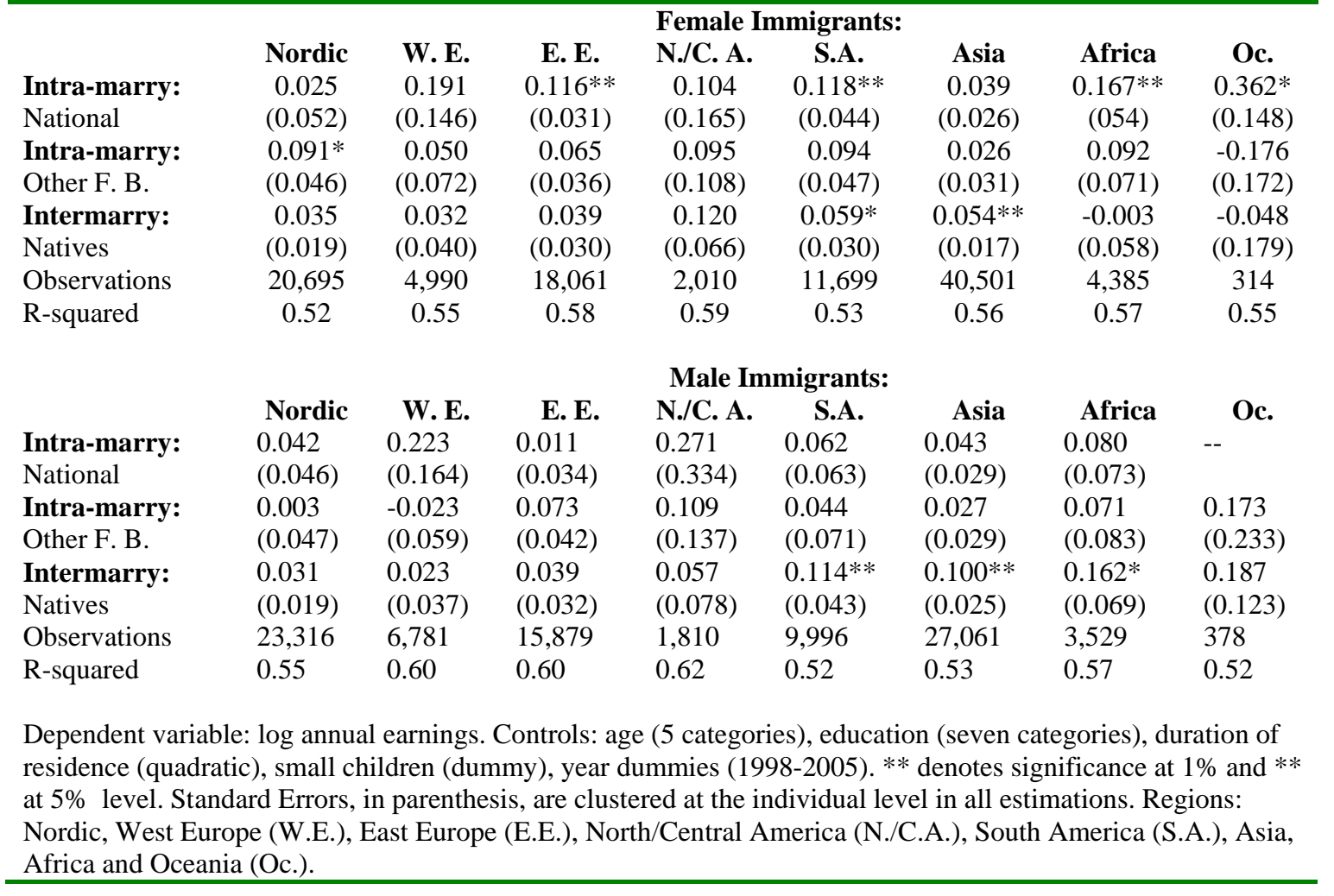

Table A4: Marriage Premiums on Earnings, by Gender and Region of Origin, Age at Migration 16-45. Fixed Effects Estimation

\begin{tabular}{|c|c|c|c|c|c|c|c|c|}
\hline & \multicolumn{8}{|c|}{ Female Immigrants: } \\
\hline & Nordic & W. E. & E. E. & N./C. A. & S.A. & Asia & Africa & Oc. \\
\hline Intra-marry: & $0.077 * *$ & $0.123^{*}$ & $0.186 * *$ & 0.256 & 0.078 & $0.115^{* *}$ & $0.105^{* *}$ & 0.325 \\
\hline National & $(0.031)$ & $(0.055)$ & $(0.027)$ & $(0.182)$ & $(0.059)$ & $(0.031)$ & $(0.038)$ & $(0.463)$ \\
\hline Intra-marry: & 0.032 & 0.031 & $0.117^{* *}$ & 0.176 & -0.016 & 0.067 & 0.113 & -0.196 \\
\hline Other F. B. & $(0.040)$ & $(0.059)$ & $(0.036)$ & $(0.124)$ & $(0.062)$ & $(0.048)$ & $(0.059)$ & $(0.303)$ \\
\hline Intermarry: & $0.041 *$ & 0.053 & 0.020 & 0.029 & $0.097 *$ & $0.082 * *$ & 0.006 & 0.354 \\
\hline Natives & $(0.019)$ & $(0.033)$ & $(0.032)$ & $(0.071)$ & $(0.049)$ & $(0.028)$ & $(0.064)$ & $(0.183)$ \\
\hline Observations & 26,497 & 10,329 & 27,743 & 3,198 & 6,742 & 25,463 & 8,251 & 570 \\
\hline \multirow[t]{3}{*}{ R-squared } & 0.56 & 0.59 & 0.54 & 0.57 & 0.55 & 0.56 & 0.60 & 0.57 \\
\hline & \multicolumn{8}{|c|}{ Male Immigrants: } \\
\hline & Nordic & W. E. & E. E. & N./C. A. & S.A. & Asia & Africa & Oc. \\
\hline Intra-marry: & 0.026 & 0.072 & $0.049 * *$ & $0.199 *$ & -0.043 & 0.023 & $0.074 *$ & 0.290 \\
\hline National & $(0.029)$ & $(0.044)$ & $(0.019)$ & $(0.093)$ & $(0.050)$ & $(0.017)$ & $(0.032)$ & $(0.445)$ \\
\hline Intra-marry: & -0.015 & 0.052 & 0.007 & 0.012 & 0.081 & -0.018 & 0.108 & 0.067 \\
\hline Other F. B. & $(0.036)$ & $(0.044)$ & $(0.028)$ & $(0.080)$ & $(0.054)$ & $(0.026)$ & $(0.042)$ & $(0.194)$ \\
\hline Intermarry: & 0.027 & $0.119 * *$ & 0.035 & $0.123^{*}$ & 0.070 & $0.077 * *$ & $0.104^{*}$ & $0.210 * *$ \\
\hline Natives & $(0.023)$ & $(0.023)$ & $(0.031)$ & $(0.055)$ & $(0.051)$ & $(0.031)$ & $(0.050)$ & $(0.075)$ \\
\hline Observations & 21,509 & 20,595 & 38,133 & 4,640 & 7,611 & 53,576 & 16,239 & 1,627 \\
\hline R-squared & 0.63 & 0.60 & 0.50 & 0.58 & 0.52 & 0.53 & 0.52 & 0.56 \\
\hline \multicolumn{9}{|c|}{$\begin{array}{l}\text { Dependent variable: log annual earnings. Controls: age (5 categories), education (seven categories), duration of } \\
\text { residence (quadratic), small children (dummy), year dummies (1998-2005). ** denotes significance at } 1 \% \text { and } * * \\
\text { at } 5 \% \text { level. Standard Errors, in parenthesis, are clustered at the individual level in all estimations. Regions: } \\
\text { Nordic, West Europe (W.E.), East Europe (E.E.), North/Central America (N./C.A.), South America (S.A.), Asia, } \\
\text { Africa and Oceania (Oc.). }\end{array}$} \\
\hline
\end{tabular}


